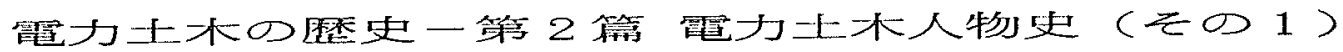

\author{
正会員 稲松技術士センター 稲松敏夫（技術士）
}

History of Electlic Civil Engineering

-Part II History of Electlic civil Engineer-

by Toshio Inamatsu.

\title{
相要 要
}

筆者は先に第 1 回〜第11回にわたって、電力土木の变僄と、電力土木に活躍した人々を中心 に、各河川の水力開発の変僄について述べその中で電力土木に一生を捧げた人々のうちの代 表的人物 60 名を発掘して、その成果をまとめ得た。今回はその中 25 名の人々の業繢を詳述して 第 2 篇 電力土木人物史として発表する。（明治～昭和期、電力土木、開発した人）

（I.分類、人物史、II. 分類、河川、エネルギー）

1. はじめに

電力土木 100 年の歷史のうち、雪力上木人物史に とりあげるのは次の 25 名と考えている。

(1)知久清之助 (2)伊滕令二 (3)内海清温 (4)北松友 義 (5)鵜飼孝造 (6)和澤清吉 (7) 大林士一 (8)市浦

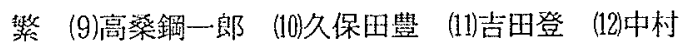
光四郎 (13)山本三男 (14)味埜稔 (15)足立正俊 (16)平 井弥之助（17)水越達雄（18)大橋康次（19)浅尾格 (20) 大西英一（21）永田年 (22) 徳野武 (23) 野瀬正義 （24）岩本常次（25）目黑雄平

\section{2. とりまとめにあたって}

25名の人物史をとりまとめるにあたって次の様に 多数の方々の御協力を得た。あつく感謝致し、心か らお礼申し上げます。

1）御家族、御漞战の御協力

電力土木人物史にとりあげた方々の中、 2 世 として電力土木並びに上木関係に献身している 方が多い。例えば、(1)知久清之助の 6 男知久徳 氏 (東電設計取締役) (2)伊藤令二の長男伊藤学 氏 (東大名誉教授、埼玉大学教授) (4)北松友義 の3 男北松治男氏 (東北電力常務取䋨役、東北 開発コンサルタント社長) (12)中村光四郎の女婿
菅野孝夫氏（サンコーコンサルタント常務）(13)山 本三男の長男山本健氏（中国電力土木部次長） (18)大橋康次の女婿暒山義夫氏 (北海道電力常務) (20)大西英一の長男大西一央氏 (日本原電常務) 等 の御協力を得た。

2）自叙伝又は随筆等を萻かれている方が多い。例 元ば(1)知久清之助 (2)伊藤令二 (3)内海清温 (4) 北松友義 (9)䯩桑鍓一郎 (19)味野稔等で参考にさ せていただいた。

3）電力土木技術協会が昨年水力百年記念事業とし て発刊された水力技術百年史を参考にさせていた だいた。

4） 10 年間にわたり毎年、全国各地を資料收集の為 廻った際、各地の方々から資料並びにお話をおき きしたのと同時に多くの先翌方に直接面談して得 た䐝重なお話をもとにして、前回の第 1 部各河川 水力開発の变䜿及び今回の第 2 部電力土木人物史 をまとめ得た。直接面談をしていただいたのは (2)伊藤令二 (3)内海清温 (4)北松友義 (9)高樊銅 一郎 (5)鵜飼䓔造 (6)和涬清吉 (7)大林士一 (8) 市浦繁 (10)久保田豊 (11)吉田登 (14)味埜稔 (15)足 
立正俊 (16)平井弥之助 (17)水越達雄 (18)大橋康 次 (19)浅尾格 (20)大西英一（21）永田年（22） 徳野武 (23) 野瀬正義 (24) 岩本常次 (25) 目 黒雄平と 25 名中 22 名である。大部分は故人とな られたが、生前、直接、間接に御指導をいただ いた方々である。

3. 人物史

1) 知久清之助

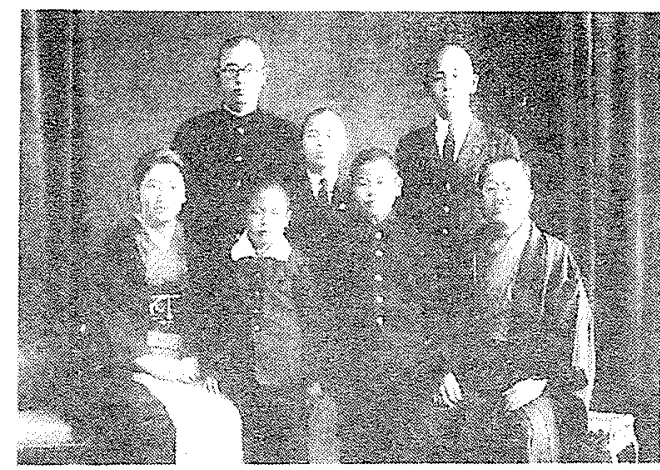
昭和13年 1月 家族挏って

イ)はじめに

炤和62年12月私は関東地方の水力開発の变䏇 を䋥めるに当たり、知久徳氏（東電設計(俶第一

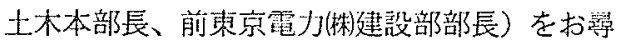
ねして、父知久清之助 (東京電灯條信潡川発電 所事務所長）自伝及び東京電力三十年史外多数 の資料を借用し、それらを参考にして取䋛めた。 お借りした知久清之助自伝は、原稿用紙に綺毗 なペン量きで、還暦を記念して丹念に生涯の記 録をまとめられた原稿を徳氏が保管されていた ものであった。その後1990年（昭和64年）8月 徳氏が父の自伝の原稿を 1 年がかりでワープロ で活字化し、印刷製本して刊行された苦心の自 伝をいただき、本稿は父清之助氏の自筆の自伝 と六男德氏の製本、刊行された父の自伝を参考 にまとめたものである。

口）知久清之助の年譜

明治19年 5 月 徳次郎、ク二の二男として誕生

（栃木県野木村、東北本線古河駋近く）

明治35年 4 月 東京郁文館中学入学

明治 40 年 9 月 第一高等学校二部甲類入学
明治 43 年 9 月 東京帝国大学工科大学土木工学科 入学

大正 2 年 7 月 東京帝国大学卒業

大正 2 年 9 月 東京倉庫会社神戸支店建設部入社

大正 3 年12月 三菱神戸造船所土木課入社

大正 4 年 5 月 梅野梅之結婚

大正 9 年 1 月 猪苗代水力電気株式会社入社

大正12年 4 月 東京電灯株式会社に合併入社

昭和 2 年 2 月 東北電力株式会社入社

昭和 3 年12月 東京発電株式会社に合併、入社

昭和 4 年12月 六男 徳 誕生

只見川筋調查実施

昭和 6 年 4 月 東京電灯株式会社に合併、入社

昭和 7 年 6 月 台湾総督府交通局に入局

昭和 8 年 4 月 台㴒移住

昭和10年 4 月 東京笔灯株式会社入社

一家台湾より引揚げ

昭和11年10月 信濃川建設事務所副所長

昭和14年＼cjkstart信滰川第一期工事完成

昭和15年10月 蘭印出張（三ケ月䦥）

昭和15年12月＼cjkstart建設部土木課長兼信濃川建設事務 所长

昭和16年 9 月 仏印出張

昭和17年 4 月 仏印調查より帰社

日本軽金属入社

昭和17年 5 月 猪苗代湖低下工事䇋工

大井川視察

昭和18年 5 月 昭南に赴任

佐野川起工、篣川視察

昭和18年11月 スマトラに赴任

昭和19年 5 月 ジャワに赴任

ジャワ軍政監部兼ジャワ雪気建設

電力部長

昭和 20 年 6 月 ジャワより昭南へ

内地帰還（佐世保上陸）

昭和 20 年 8 月 終戦

炤和20年11月 陸軍臨時㩔託解除

昭和21年 1月 鎌倉転居

昭和 21 年 3 月 日本軽金属退社

昭和 21 年 5 月 還暦

自伝原稿執筆を始める。

昭和 22 年 鎌倉彫入門 
昭和 23 年 5 月 東京転居

昭和 24 年 4 月 竹内建設株式会社入社副社長

昭和 26 年 8 月 㹟心症にて死亡

享年66才

八）猪苗代水電時代（大 9.1-大12.3）

社長 仙石貢 (鉄道大臣となる) 部長 井上 秀二のもとで吾妻出張所長として、猪苗代第 3、 猪苗代第 4 発電所の建設を担当した。

檜原湖々面低下工事にも挺身した。

二）東電建設部時代（大12.4-昭 2.2）

建設部土木係長として、関東大震災後の山梨 県桂川水系復旧工事を担当した。

社長 神戸挙一、副社長 若尾璋八、建設部長 広瀬為久、建設部副部長 井上秀二、土木課長 神原信一郎氏の指導を受けた。千石社長は東笔 相談役となった。当時の建設部土木課関係の仕 事は、利根川水系上久屋発電所建設中、信濃川 水系関山発電所の着工準備、猪苗代水系の第 3、 第 4 発電所調查設計、利根川水系の栗沢地点、 岩本地点、赤谷川地点、島川地点等の調查、設 計等多忙であったが大正 12 年の 9 月 1 日の関東 大震災により調查方針を変更した。ついで関東 大震災の山梨県桂川の各発電所 (八ツ沢、巸橋、 谷村、鹿留等) の復旧班（班長奥村筒二）とし て活躍した。

さらに、上久屋発電所の竣工、関山発電所の着 工、13年猪苗代第 $3 、$ 猪苗代第 4 発電所の同時 着工、猪苗代送電線、及び花畑及び萓付变電所 の建設並びに千住火力発電所 ( 5 万 $\mathrm{kW}$ ) の建設 等大正15年それぞれ完成した。

木) 東北電力時代 (東京電灯傍系) (昭 2.2-3.11) 社長 酒井伯、副社長 河西豊太郎、専務 田辺七六、建設部長 奥村管二で福島県野沢発 電所主任として、高橋清蔵技師を次席として、 野沢発電所建設及び沼沢沼揚水発電所の調查を 奏施した。

へ) 東京発電時代 (東京電灯傍系) (昭3. 12-6.3) 東京電灯は傍系の東北電力及び信越電力並び
に関東水力の三社を合併して東京発電(敉を創設し、 社員は全部新会社に引継いだ。知久清之助は理事 に任ぜられ建設部調查課長を命ぜられた。

社長 小林一三、副社長 河西豊太郎、専務 田 辺七六、及び八巻弥一、建設部長 多田耕三、建 設部次長 奥村管二、土木課長 大島満一（知久 氏と同級生）、調查課長 知久清之助、土木課副 長 加藤貢 (知久氏の 2 年後輩) であった。土木 課は信濃川地点の建設担当、調査課は、只見川地 点の許可促進業務を担当した。

卜）東京電灯嘱託時代（昭 6.4-7.6）

発電計画課勤務。東京発電(鉂が解散して電京電 灯に合併されたので、残務整理の為、東京電灯啒 託として勤務した。不遇の時代であった。

チ）台湾時代（昭 7.6-10.4）

昭 7 年 6 月東電嘱託森忠蔵氏より台湾行きを奨 められ、鵁慮の結果、東電重役の了解を得て、依 願解職となった後、之に応じ、直ちに赴任の途に ついた。

台湾電力(㹯)日月潭水力発電所工事監督として、総 督府交通局手信部の啒託として赴任した。3 年間 日月潭発電所 10 万以の完成に努力した。台湾電力 建設部長 新井栄吉、日月潭建設所長 石井林次 郎、土木係長 品川善次郎で全線を六工区に分け、 それぞれ工区主任を置き、各工区とも当時着工し ていた。

総督府側の監督組織は、森忠蔵を首班とし、現場 駐在員は森田利吉（日月潭眝水池の土堰堤監督を 専門) 知久清之助（トンネル及び発電所等全線、

每月 3 回程度巡回監督）の 2 名であった。昭和 9 年10月発電開始した。

その後、台湾各地の新規開発地点の調查計画を担 当した。

リ）東京電灯信涉川水力発電所建設事務所長時代 (炤10.4-15.12)

東電副社長 河西豊太郎の招へいで台湾を引揚げ た。東京電燈信濃川水力発電所建設事務所副所長

（後に所長に昇格）となった。

大島満一は小野川発電所建設事務所長（猪苗代湖 
方面）、加藤貢は本部の土木課長となった。信 浱川建設所長は三野熊雄建設部長の兼務、副所 長 知久清之助は、次席技師 古川運造等と現 地調查、請負付託等に専念、昭和11年11月 1 日 に着工した。17万kWを一期工事、二期工事に分 けて、一期工事昭和14年11月竣工、二期工事昭 和16年 4 月竣工。請負は飛島組、大林組、水門 石川島、鉄管 三菱重工業、建物鉄骨 横河橋 梁、水車はホイト社、発電機はA.E. G. 主変压器 は芝浦製、屋外変電所は富士電気で施工した。 トンネル延長 $23 \mathrm{~km}$ 。昭和 16 年信濃川発電所の設 計、施工に新機軸をだし、発電事業に功労あり たりとなし、電気学会より、大島、加藤两氏之 連名で表彰状並びに金一封を又同一の理由で、 日本発明協会より賞碑及び表彰状を受領した。

\section{叉）蘭印出張（昭15.10-15.12）}

小林一三商工大臣（前東電社長）の要請で、 新井社長、安藤副社長、佐藤部長より䦥印出張 の命を受け、山口直樹を随行、日軽金常務、上 島清蔵の指揮を受け、電源開発の調查を実施し た。セレベス島トウチ湖のラロナ河の発電計画 並びにスマトラ島トバ湖のアサハン河の発電計 画等の踏查を行った。

\section{ル）東電土木課長時代（昭15.12-17.3）}

東電土木課長大島満一、朝鮮の黄海水力電気 会社の技師長兼重役に転出のあ之、知久清之助 が、東電土木課長に任ぜられ、猪苗代湖面低下 工事を推進。16年 2 月着工、建設事務所長は小 野口貞技師であった。請負は飛島組で施工した。 昭和17年 5 月竣工した。

信濃川、小野川、秋元各発電所の従業員とも、 日本発送電株式会社に引き継がれる事となった。

\section{オ）佛印出張（昭16.9-17.4）}

日佛共同で佛印の産業資源開発の為、調查団 を派遗。調查団は鉣業、農業、水産、林産、綿 業、糖業、水力等十数班に分かれ、調查員二百 数十名の大団体で、知久清之助は水力班に属し た。水力班は聥信省電気課の弘山技師を班長之 し、莪信省水力課の岡崎技師、日発会社の宮川
技師之東電の知久技師の 4 名で外に助手 2 名通訳 1 名の総員 7 名から成っていた。調查地点は八ノ イを中心として、トンキン地方のルージ河(紅河)、 クレール河（清河）の諸地点を始め、アンナン地 方のサムリン、ユエ等を中心として付近の数河川 を調查し、一部ラオス地区にも出入りした。さら に、サイゴンの近くで数ケ地点を調查した。また、 メコン河を遡り、ラオス地方に入り、コーンの瀑 布（夕イ国側）、プノンペンより大湖（グランラ ック）を視察、昭和16年12月 8 日の米英との開戦 の報はこの時ラオカイで聞いた。

ワ）日本軽金属(踭電力建設部長時代(昭17.4-18.9) 17年 4 月佛印より㷌るや日本㪕金属㑣電力建設 部長として東京電灯(㑣)の安蔵副社長の推萀で入社 した。日本軽金属㑣はその有する富士川系三発電 所の総出力10万キロを総べて、自社の蒲原工場の アルミナ電解に消費していた関係上、自家発電所 として保有し、更にその工場拡張計画に伴い、そ の水利権を持っていた大井川上流井川地点に発電 所を開発する為に入社した。

大井川、井川地点及び新潟県三面川の水力開発調 查計画と富士川筋の既設、波水井、富士川第一、 富士川第二の総出力 10 万 $\mathrm{kW}$ 補修及び増強建設工

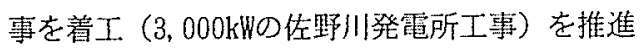
した。

力）南方勤務時代（昭18.9-20.8）

日本軽金属侏、昭南支社長代理として昭南島に に勤務。昭和19年 5 月ジャワ電気事業社建設局長 (関東配電会社の傍系会社、社長は佐藤穞德氏) として、ジャワ島の水力発電所の建設、調查に従 事した。

大東理戦の進展と共に、アルミニュームの需要 は漸次増加したが、其の資源は主として、南洋旧 䕡印ビンタン島のボーキサイトに依存して居たの で、若し現地でボーキサイトをアルミナに製造し て内地に搬入すれば、船腹は正に半分で足りる事 となり、又、貧鉱処理にも便利となるので、昭18 年夏、日本軽金属はビンタン島に差当たり年産 10 万トンのアルミナ工場を建設すると同時に当時日 窒会社よりスマトラ島で建設に着手していたトバ 
湖を水源とするアサハン河の水力発電所の電力 を利用して、スマトラ島に年産 2 万トンのアル ミナ電解工場即ちアルミニューム製造工場を建 設する為に、昭南支社を創設し、支社長 西田 伝五郎博士（清水のアルミナ工場長）、知久清 之助は参与に任ぜられ、支社長代理を命ぜられ た。昭南市のビンタン島の工場建設事業及びス マトラ島アルミニューム工場建設並びにジャワ 島の10ケ所の水力発電所の調查、建設及び 2 ケ 所の火力発電所の移設工事、送電線の建設等に 挺身した。

ヨ） 20 年 6 月、昭南より㷌䢱。 21 年 3 月、日本軽 金属(㑣依覑解啒。

26年 8 月15日 狭心症で死去。66才

\section{夕）私の知久清之助観}

電力土木に一生を捧げた人々の中第 1 号に知 久清之助を選んだのは、東京電力の信濃川建設 工事を始め日本国内の水力開発の歴史の一時代 を作ったと共に、世界大戦時代の台湾電力日月 澄工事、闌印、佛印等の電力開発に挺身した幅 広い電力上木の先達として、その自分史を克明 に、家族の為、国の為に残された偉業に心打た れたからである。大正 2 年東大上本を卒業後、 昭和26年死亡するまで38年間、電力土木の歷史 を国内外に筑き上げた先達の一人であると共に、 知久徳の親子二代電力界に挺身した事も感銘樑 い。

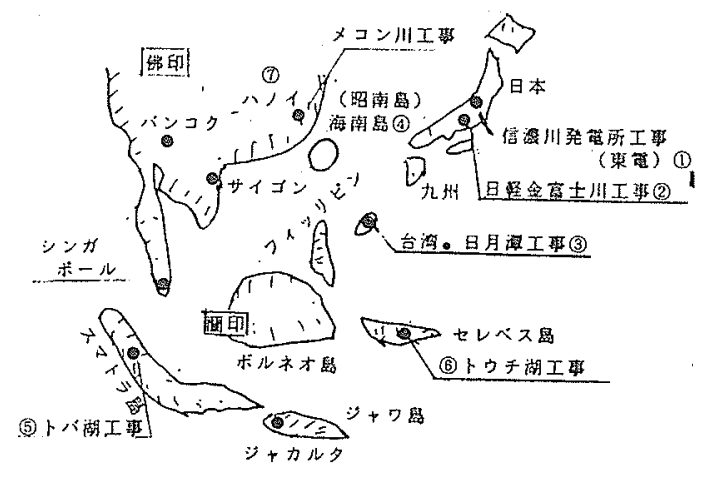

知久清之助の足跡
2）伊藤 令二

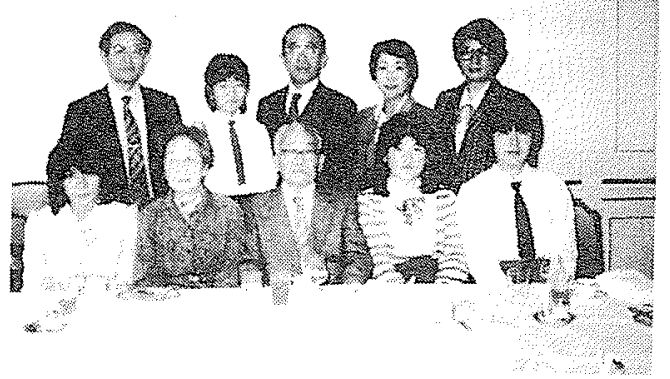

昭和 60 年 3 月 家族揃って

イ)はじめに

平成 4 年 6 月土木史研究発表会が埼玉大学で行 なわれ、私が電力土木史（その11）を発表した際、 伊藤学先生（東大名誉教授、埼玉大学教授）にお 会いして父伊藤令二が自叙伝 “思ひ出の記”を発 刊して、富山県電気局時代の有峰夕゙ム建設所の勤 務時代の事も書いており、伊藤学先生も富山大学 付属小学校に通ったので富山が懐かしいとの話が でて一冊送っていただいた。 土木史研究№.11に伊藤令二の略歴を私が記載した ので、今回は「思ひ出の記」を中心に一生を土木 事業、特に日本のダムの代表的な工事一有峰ダム、 奥只見ダム、御母衣ダム（日本最初のロックフィ ルダム）に挺身した伊藤令二を人物史第 2 号にと りあげた。

口）伊藤令二の年譜 明治 35 年 9 月 2 日 金次郎、きくの五男として誕 生 (静岡県婈津市)

大正 9 年 3 月 静岡県立藤枝農学校卒業 大正10年 3 月 私立豊山中学校(東京)四学年終了 大正13年 3 月 第八高等学校理科卒業

昭和 2 年 3 月 東京帝国大学工学部土木工学科卒 業

昭和 2 年 4 月 内務省土木試験所雇

昭和 7 年 7 月 内務技師横浜土木出張所勤務 昭和 9 年 6 月 内務省清水港修筑事務所主任 昭和11年 5 月 富山県土木技師兼道路技師 富山県電気局喝託（有峰発電所工 
事堰堤主任及電気局土木課工務 係長を歴任)

昭和16年 8 月 内務技師東京土木出張所勤務 昭和16年10月 内務技師鬼怒川改修事務所長 昭和17年 3 月 国土局河川課勤務。水力及河水 統制係を担当

昭和18年 1 月 満洲国へ出張

昭和19年 2 月 中華民国へ出張

昭和23年 1 月 総理庁技官、建設院勤務 建設院水政局利水課長兼砂防課 長

昭和 23 年 7 月 建設技官、河川局利水課長 昭和23年11月 建設省中部地方建設局長 昭和 24 年 9 月 建設省中国、四国建設局長 昭和25年12月 日本学術会議会員に当選 昭和 25 年 12 月 国際大ダム会議 (インド) 出張 昭和 27 年 5 月 工学博士

昭和 27 年 12 月 建設省関東地方建設局長

昭和28年12月 東京電力(侏入社 参事、建設部次長

昭和29年 7 月 東京電力(姝建設部長 昭和 29 年10月 奥只見建設所長 昭和 31 年 7 月 東京電力(制退職 電源開発(俐土木部長

昭和 32 年 3 月 電源開発(䟻御母衣建設所屒 昭和34年 5 月 電源開発(㬨土木部長（役員待遇） 昭和 34 年12月 台湾入出張 昭和 35 年 2 月 電源開発㑣理事

昭和36年 6 月 国際大夕゙ム会議（ヨーロッパ及 びアメリカへ)

昭和38年 3 月 水資源開発公団、ダム技術委員 会委員

昭和39年 2 月 電源開発(搳理事退任

昭和 39 年 2 月 大豊建設(㑣顧問

昭和39年 5 月 開発コンサルタント(知取締役社 長

昭和42年 4 月 埼玉大学理工学部煐師

昭和44年10月 日本ダム協会会長

昭和47年11月 勲三等瑞宝章

昭和51年 6 月 開発コンサルタント(㮫取締役社 長退職

平成 2 年 8 月 死去 87 才
伊藤令二の足跡

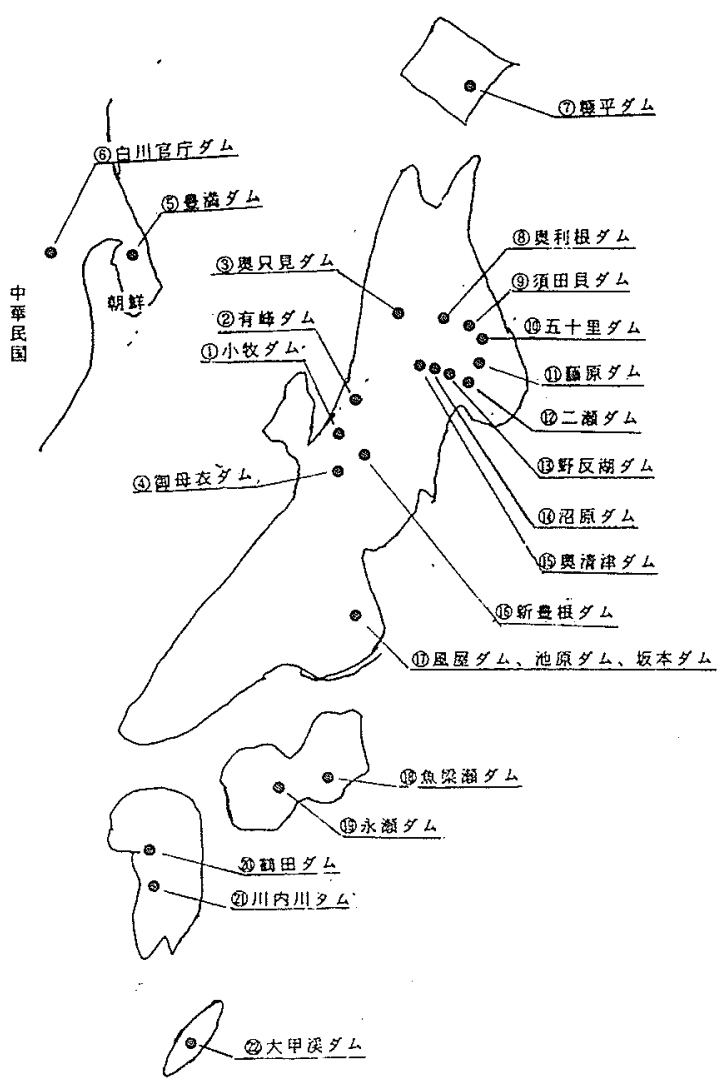

八）東大 3 年の夏期実習に富山県圧川の小牧夕゙ム建 設工事現場へ行く。（昭和元年 8 月） 当時、日本一のコンクリート重力ダムであった。 所長は石井穎一郎で物部長䅹東大教授之同期生。 実習の指導は先覇藤井雄之助であった。 同級生の伊藤信と 2 人で実習を終えて、2人は夕゙ ムを造る東京電力へ就職しようと話しあった。 卒業諭文は「アーチダム」を書いた。

二）富山罢へ出向、有峰ダム建設事務所ダム主任と なる。（昭和11年 5 月 -16 年 8 月）

内務省清水港修築事務所長上り富山临電気局有峰 ダム建設事務所ダム主任となった。 電気局土木課長は金野賢也、有峰ダム建設事務所 長は藤原琢爾であった。電気局電気課長は永井要 蔵。電気局技師野際幸雄（女優野際陽子の父）で あった。 
有峰ダムは常願寺川支流和田川の上流で高さ110 $\mathrm{m}$ 、体積 70 万 $\mathrm{m}$ の当時日本最高の重力式、コン クリートダムである。ダムのコンクリートの打 設は昭和14年より開始したが、昭和16年日本発 送電に委譲され、伊藤令二には16年 8 月内務省 東京土木出張所へ転勤となった。〔筆者は昭和 17年 9 月日本発送電(侏北陸水力事務所建設課設 計係へ入社し、設計係長代理 大橋康次 (元北 海道電力副社長）のもとに有峰夕゙ム建設事務所 の業務特に水資料の検討等も担当した。昭和 19 年 6 月、セメント等の資材不足の為、工事中止 となった。中止当時コンクリート高さ $5 \mathrm{~m}$ 打設 ずみであった。

昭和31年北陸電力有峰ダム建設所 (所長 大林 士一) 及び常願寺水系発電所建設所（所長 和 沢清吉）で有峰ダム工事、和田川第一、第二発 電所等10発電所28万kWの工事が再開された。 有峰ダムは既打設コンクリートを中に含んで、 高さ $140 \mathrm{~m}$ の重カコンクリートとして昭和 34 年 完成し、引き続き昭和53年增設工事を着工、常 願寺水系建設所（所長高瀬博）で有峰第 1、第 2 、第 3 等 40 万 $k$ Wの発電所が昭和 56 年運転開始 した。

六）内務省東京土木出張所鬼怒川改修事務所長時 代

五十里ダム調查担当（昭和16年10月）

当時、ロックフィルダム建設の調盉をしたが、 その後、ダム位置を下流に変更、重力ダムで建 設した。

へ）朝鮮の水豊ダム視察、満洲土木学会に出席の ため立ち寄る（昭和18年 1 月）

鴨緑江で建設中の水䅱ダム（建設所長 学友 松尾次六) 見学

ト）中華民国北支白川の宫打ダム現地調查 （昭和19年 2 月）

商工省の高畑政信之 2 人出張

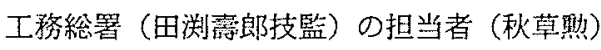
案内。

また北京の華北電業担当者（落合久四郎）の案
内で北支の電力建設を視察した。

チ）「堰堤工学」を出版（20年 3 月〜 22 年 2 月） 有峰ダムの建設計画、実施の経験を中心として、 ダムに関する本を出版した。

リ）建設省利水課長時代矢木沢ダム調查、計画 （昭和23年）

矢木沢ダム担当 (小池挙)

その後、水資源公団で完成。

邓）建設省中国四国地方建設局長時代、永瀬ダム完 成（昭和24年）

四国物部川工事事務所（永瀬夕゙ム）所長山崎博、 土木課長 豊田栄一。ほかに、中村慶一、堀内弘 顕、池上雅夫等担当。

重力式コンクリートダム 高さ $85 \mathrm{~m}$ 。

ル）昭和天皇四国地方御巡幸の際、渡川（四万十川） 改修工事につき説明（昭和 25 年 3 月）

現在、渡川流域の発電所 7 ケ所、最大出力 4 万 $\mathrm{kW}$ 。

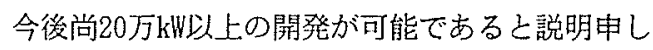
上げた。この時、阵下御年48才。伊藤令二は47才 であった。

オ）日本学術会議会員に当選（昭和 25 年 12 月）地方 区、中国四国地区の第五部（工学関係）に当選。 現在、長男 伊藤学 日本学術会議会員で親子二 代 会員である。

ワ）山口県佐波川ダム工事の委託を受けた。 （炤和25年）

コンクリート重力ダム、工事事務所長（平田正二） 工事担当、增岡康治、伊達克己。

カ）東大から工学博士を授与（昭和27年 5 月）論文 「太田川洪水の出水解析と淇水予報」

ヨ）建設省関東地方建設局辰時代

五十里ダム（鬼怒川）、藤原ダム（利根川）、二 瀨ダム（荒川）等を指導した。 
夕）東京電力八入社、建陪部次長（昭和28年12月） 先毣萩原俊一氏の推薦で、東京電力做入入社。 大学時代に墥れた東電へ 27 年目で初志貫徹した。 建設部次長を洋命。29日7月建設部長となる。 須田貝ダム (利根川上流)、〔コンクリート重力 式の大ダム及び我が国初めての地下大発電所工 事) 及び奧利根建設所 (所長 鈴木忠男) 並び に野反湖ダム（群馬県、新潟県境）建設所（所 長本間徳雄ロックフィルダム高さ $30 \mathrm{~m}$ ) の3ダ ムを在任中、完成した。

レ) 電源開発(橵へ出向、奥只見建設所長となる。 (昭和29年 9 月)

奥只見ダムは当時日本一の大ダム。コンクリー 卜重力式高さ $155 \mathrm{~m}$ 。堤体積 170 万 $\mathrm{m}^{3}$ 。貯水量 6 億 $\mathrm{m}^{3}$ 。（現在でも日本一）発電所地下式。出 力 36 万 $\mathrm{kW} 。$

ソ）東京電力退職。電源開発㑣上木部長となる。 (昭和31年 7月)

電源開発総裁。小坂順造 後内海清温。 土木担当理余 斉藤三郎 後 永田年 (佐久間 建設所長) 土木部長 伊藤令二

御母衣建設工事之奥只見建設工事の請負入札を 行う。

ツ）電源開発㨆御母我建設所長（昭和32年 3 月）

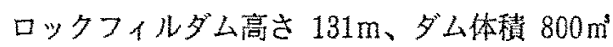
当時としては日本では画期的な大口ックフィル ダムであった。

発電所（地下）出力 35 万W、眝水監 4 億トン. ダム工事聞組担当。

電発橵多么主任 浅尾格。工事中に伊丹康夫 (大型建設機械の運用) 三国英四郎（堤体コア 一の土質の問題) 浅尾格（ロックフィルダムの 技術的問題) の三人が博士号を東大から授与さ れた。

ネ）昭和34年 5 月本社土木部長（役負街遇）に転 勤。後任の御母衣建設所長は浅星格となる。

ナ）台湾へ出張（昭和 34 年12月）
台湾電力大庙渓の達見ダムの建設計画について助 言。

ロックフィルダム。

日月潭ダム。嘉南大圳ダム〈田与一が心血をそ そいだ農業用ダム、八田堰堤と名付けられている。 東大土木出身) 等を視察した。

ラ）電源開発の理事となる(昭和35年2月)

奥只見、田子倉、御母衣の三大プロジェクトが相 ついで完成した。

(理事在任中の建設工事)

1）西吉野川第 $1 、$ 及び第 2 発䉓所（熊野川筋、 十津川及び北山川）並びに猿谷ダム、風屋ダム、 二津野ダム

2）池原ダム (北山川筋)

アーチダム及び池原発電所（35万hWの混合揚水 発電所)

3）七色ダム (北山川筋) 小森ダム及び七色発電 所、小森発電所

4) 坂本ダム (アーチダム) (北山川筋) 及び尾 跑第一、尾䇥第二発電所

5）北海道糠平名ム（十勝川） 㴍平発電所及び芽登第 1 並びに芽登第 2 発電所、 足寄発電所。

6）四国、魚梁瀬（やなせ）ダム（奈半利川）及 び魯梁瀬発電所主びに二又発電所、長山発電所。

7）九州、瀬戸石発笔所（球鹰川）及び川内川第 一発電所 (出力12万 $\mathrm{kW}$ ) 及び川内川第二発電所 (1万5千kW) 鶴田ダム（高さ $117 \mathrm{~m}$ 、重力ダ ム) 建設省で施工。

8）新慧根揚水発電所（天竜川水系） 高さ $117 \mathrm{~m}$ のアーチダム (上池)、传久間拧 水池 (下池) 出力 112.5 万 $\mathrm{kW}$ 揚水発電所。昭 和 48 年完成。 
9）沼原揚水発電所（栃木県那埼川）樑山ダム (農林省建設) 下池 沼原調整池 上池 落差 $528 \mathrm{~m}$ 、出力 67.5 万 $\mathrm{kW}$ 揚水発電所。

10）奥清津揚水発電所（新潟県信濃川の支流清 津川)

落差 $500 \mathrm{~m}$ 、出力 100 万 $\mathrm{kW}$

昭和53年発電開始等の工事の指導をした。

さらに海外の技術協力として、

1）南米ペルー国、タクナ開発事業

$900 \mathrm{~m}$ の落差、 3.5 万 $\mathrm{kW}$ 。昭和 42 年に完成。

2)トルコのハサン、ウールル開発計画

高さ $175 \mathrm{~m}$ 、眝水量 11 億 $\mathrm{m}$ の大ロックフィル

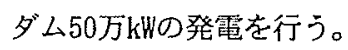

昭和 47 年着工、第 1 期工事 25 万 $\mathrm{kW}$ 、昭和 54 年 に完成。建設所長 細谷浩正 自動車事故で 殉職。

3）タイ国、シーナガン開発計画

昭和37年頃より協力。高さ $140 \mathrm{~m}$ のックフ イルダム。総眝水量 177 億 $\mathrm{m}^{3}$ 最大 72 万キロ の発電を行う。昭和 49 年着工、 55 年第 1 期工 事（出力 36 万キロ）完成。

ム）国際大ダム会議（イタリヤのローマ）に出張 (昭和 36 年 6 月)

団長 永田年、副団長 伊藤令二日本上り 21 名参加。ヨーロッパ、アメリカを視察。

ウ）電発理事退任（昭和39年 2 月）

後任の土木担当理事に浅尾格就任。

1）大豊建設に入社顧問（昭和39年 2 月）

ノ）開発コンサルタント社長となる（昭和 39 年 5 月)

大豐建設の傍系開発コンサルタントの社長と なる。

オ）埼玉大学理工学部講師となる（昭和42年 4 月）
ク）日本ダム協会会長となる（昭和44年10月）

ヤ）鷁三等瑞宝章叙勲（昭和47年11月）

マ）開発コンサルタント(株取締役社長退任。73才。 12年間社長をつとめる。

ケ）水資源公団、ダム技術委員会委員となる （昭和38年 3 月）

理事 阪西徳太郎の発案。公団の設計、施工する ダムについての重要事項について、その道の権威 者の意見を聞くためである。毎年 1 回、計画、施 I中のダムの現場へ出張してダムの地質、計画施 工方法等について公団側の計画の説明をきき、こ れを審議検討した。

$$
\begin{aligned}
& \text { 委 員 } \\
& \text { 岡本舜三（構造物の耐震） } \\
& \text { 国分正胤（コンクリート） } \\
& \text { 広田莠一（地質） } \rightarrow \text { 村 幸雄 } \\
& \text { 畑野 正 (設計の理論家) } \\
& \text { 伊藤令二（現場経験） } \\
& \text { 山本三郎 (公団前総裁) } \\
& \text { 望月邦夫 }
\end{aligned}
$$

\section{検討したダム}

1. 下久保ダム（重力式コンクリート）

利根川支流神流川

昭和 41 年、 43 年の 2 回

2. 高山ダム、青蓮寺ダム、室生ダム

（奈良県、三重県）

3. 布目ダム（奈良市の水道用水）木津川支流布目 川

重力式コンクリート、R.C.D.工法

4. 草木ダム（渡良瀬川）

重力式コンクリート

5. 矢木沢ダム（利根川水系）

アーチダム 
6. 奈良俣ダム(利根川上流)

昭和55年現地視察

高さ $155 \mathrm{~m}$ 、堤体積

1,310万 mの大ロックフィルダム

7. 阿木川ダム（木曾川支流阿木川）

昭和53年

ロックフィルダム

8. 味噌川ダム（木曾川上流）

昭和62年現地視察

ロックフィルダム、高さ $140 \mathrm{~m}$

堤体栍 650 万 $\mathrm{m}^{3}$

9. 浦山ダム及び滰沢ダム

(埼王県流川上流)

浦山夕゙ム 高さ $155 \mathrm{~m}$

堤体樻 170 万 $\mathrm{m}^{3}$ のコクリート重力ダム

昭和55年現地視察

フ）私の伊藤令二観

大学実習時代に富山県小收ダムでダム工事を 経驗し、生涯をダム工事に挺身する事を決意し て、東京電力八就睵する事を友人と話しあった のが、ダムとの出会いで、その後建設省に入っ て富山県へ出问し、有峰ダム主任の経験、さら に東京電力、電源開発に入って、奥只見ダム建 設所長、御母衣多ム建設所長等、それぞれ当時 日本一の規模の大工事に直接挺身して、最後に は電源開発の理事として、国内外のダム工事に 一生を捧げ、そのダムの業績は国内30数ヶ所に 及び、国外は戦前の台湾、朝鮮、中華民国、さ らに戦後のペルー、トルコ、タイ等の10数所 に及び、昭和 2 年より昭和 51 年の 50 年に及ぶ、 建設省湴びに電力栄界における足跡は、日本電 力土木史のダム開発隆盛期における主力的な活 躍のも之、多数の画期的ダムの設計、施工、特 に大規模、重力コンクリートダム、アーチダム、 ロックフィルダム及び地下発電所、揚水発電所 の新技術開発等、後坦に残した偉業の数々に敬 服すると其に、長男伊藤学氏とともに、親子二 代の土木関係の日本学術会議会員として、さら
に土木技術関係の指導者ししての親子二代にわた る偉業に頭が下がる。

特に有峰ダムの関係で、富山市に居住した伊藤 親子（昭和11年 5 月～昭和16年 8 月の 5 年間）の 離任直後、富山の日本発送電(㑣)北陸水力事務所に 入社し、電力界入第 1 歩を踏み出した筆者が、最 初に担当した業務が大橋康次設部係長代理（もと 北海道電力副社長）のもとに、有峰ダムの水収支 関係の仕事であり、その後富山に居住して一生を 電力土木界に捧げた筆者の感慨は、特に伊藤令二 に親近感を覚えると共に、その後、伊藤令二が小 牧ダム御母衣ダム、舆只見ダム等、関係した各ダ 厶発電所を見、今自叙伝「思ひ出の記」を読み返 して、身近に伊藤令二の偉業を心に体に感得する 事が出来る。

\section{参考文献}

1）知久清之助自叙伝

2）伊藤令二著「思ひ出の記」 1990年 8 月 第一量房

3）䉓力土木技術協会「水力技術百年史」 1992年 5 月 


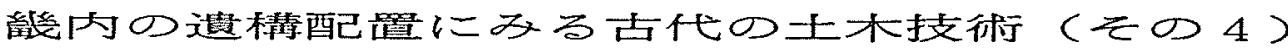 一者都市言十画基本線の検証（II）}

侏建設技術研究所 正会員，須股 孝信

The Ancient Civil Engineering on Ruins Arrangement in Kinai Area (Part 4)

-Verification of Trunk Survey Lines for Urban Planning(II)

by Takanobu Sumata

要旨

（その 1) 〜 (その 3） ${ }^{11}$ では、古代の畿内に東西・南北の直交座標軸之都市計画基本線（仮称） が置かれたことを提唱し、基本線存在の検証と使用尺度の考察により、地図作成を意図する18里方 格網設定の計画測線として存在したことを述べた。

本稿では基本線設置の検証として、古代中国の数学書『九章算術』，测量学書『海島算経』の設 問例と、方格法による科学的地図作成の祖・裴秀による「地図作成の 6 つの原則」の両者から、3 世紀の中国の测量技術が『九章算術』『海島算経』に基づいていること、4 世紀の狇内に置かれた 基本線は中国の测量技術と同じであることを明らかにした。また7〜8世紀造営の畿内の都城には 地理・地形重視と基本線の要点重視の両者があり、前者の寿命は長く、後者は短命で遷都を余儀な くされていることを明らかにし基本線存在の傍証を示した。（測量・度量衡・都市計画）

\section{1.まえがき}

前槁（その 3) では図・1の基本線と方格網が古代の畿内に計画されたことを述べた。古代中国の数学。 測量学書『九章算術』『海島算経』の設問によれば、中国の古代地図作成の技術は直角三角形を用いる数学 ・湖量術によったことか明らかである。

この数学・测量学書は古代の朝鮮半島, 日本に多大の影響を与えたことが確かであり、4世紀頃の日本に おいて巨大古鏆・池清等築造の大土木事業を成し得たのも、それらの数学・湘量技術の日本への輸入（或い は、それらの素養ある技術者集団の渡来）を示すものであろう。これらの大土木事業を可能にした当時の国 家権力から考えれば、4 世紀の日本においても、中国と同様、国の施策として地図作成を目的にした測量が 実施されたと考えるのが至当である。

\section{2.『章算術』『海島算経』の成立之普及 ${ }^{21}$}

中国科学の中で古くから高度な発達を遂げた分野は数学, 天文学々医学である。『九章算術』は先秦以来 の数学的知識を集大成した算学書で、紀元前100年から後100年の 200 年間に幾人もの算学者の補修編算を 経て成立した。その名が示すように九つの巻からなり、246の問を収録、それぞれに答えと計算法が示され ている。成立時の書と現本とは若干異なる。現本は 3 世紀半ば劉徽によって巻末に 1 巻が加えられ、さらに 全巻の問には註と図が挿入された。測量学書『海島算経』は巻末に加えられた 1 巻である。

九章算術の名は 2 世紀には定着し、唐六典によっても、劉徽註をテキストとする算学制度があって社会に 普及し、この制度は中国に止まらず、朝鮮半島・日本にも多大の影響を与えた。『三国史記』によれば新羅 （前57〜後935）は唐に倣い算学教育を行ったという。日本においても『令義解』（834）巻三・学令に九章, 海島を習え、の記述が見られる。 


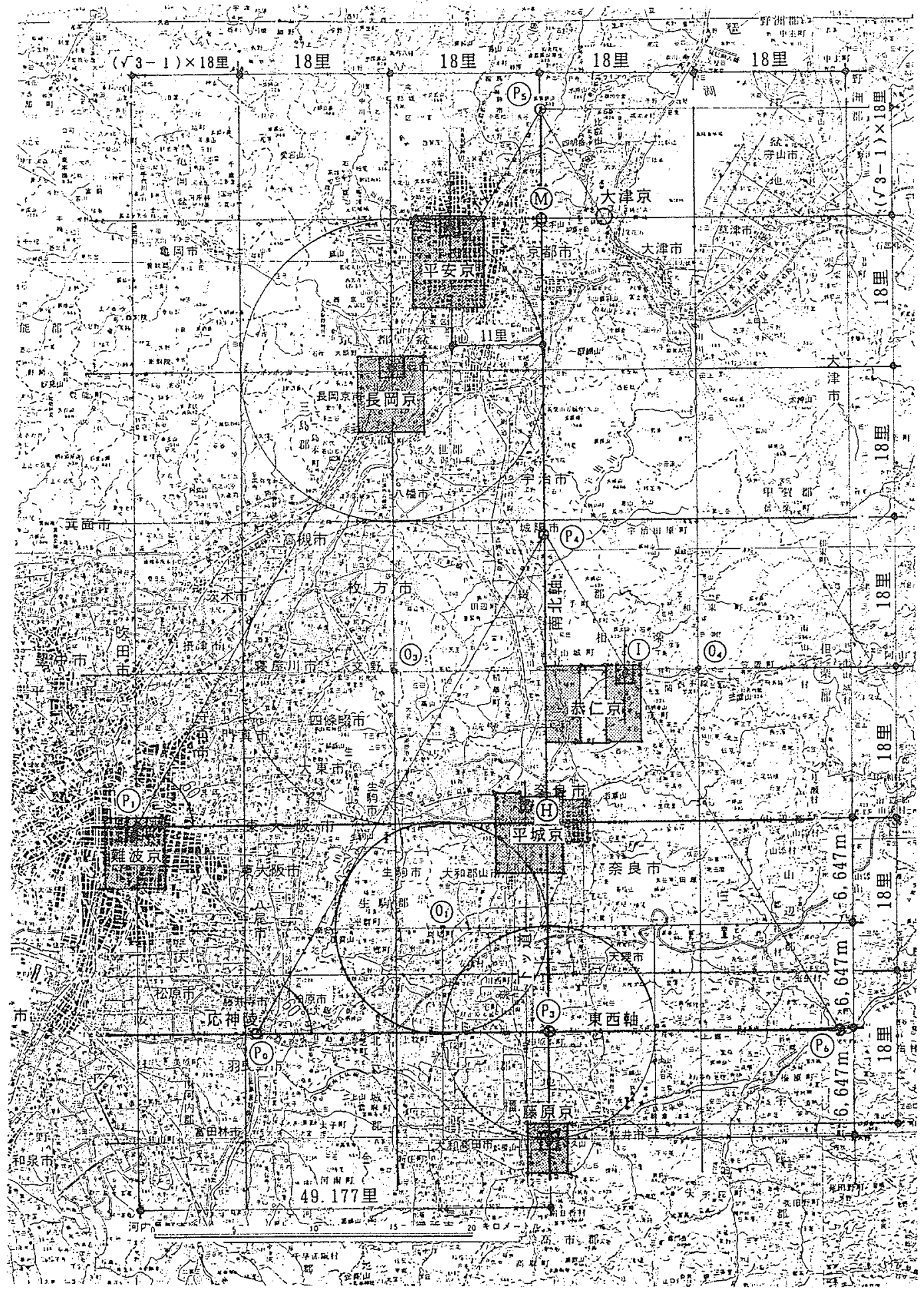

図・1 尺29.4cnによる18里方格と 7〜8 世紀造営の都城位置 